\title{
Expansion of a Myeloma-associated Lesion from Orbita to the Cerebrum
}

\author{
Orbitadan Serebruma Kadar Uzanan Miyelom ile Iliş̧kili Lezyon
}

\author{
(D) Sinan Demircioğlu ${ }^{1}$, (D) Demet Aydoğdu ${ }^{2}$, (D) Özcan Çeneli ${ }^{1}$ \\ ${ }^{1}$ Necmettin Erbakan University Meram Faculty of Medicine, Department of Hematology, Konya, Turkey \\ ${ }^{2}$ Necmettin Erbakan University Meram Faculty of Medicine, Department of Radiology, Konya, Turkey
}

To the Editor,

Involvement of the central nervous system due to multiple myeloma (MM) is a very exceptional presentation with an estimated rate of $1 \%$ of all cases [1], showing a poor survival duration of 1-2 months $[2,3,4]$. This involvement may present in three different patterns: 1) solitary plasmacytoma, 2) multiple plasmacytomas, and 3) cerebrospinal fluid involvement with plasma cells [5].

A 64-year-old female diagnosed with MM IgG kappa for 1 year was admitted with swelling and pain in the right eye. Physical examination was remarkable for proptosis. Laboratory evaluation revealed normocytic anemia, hypercalcemia, and $\mathrm{M}$-protein peak in

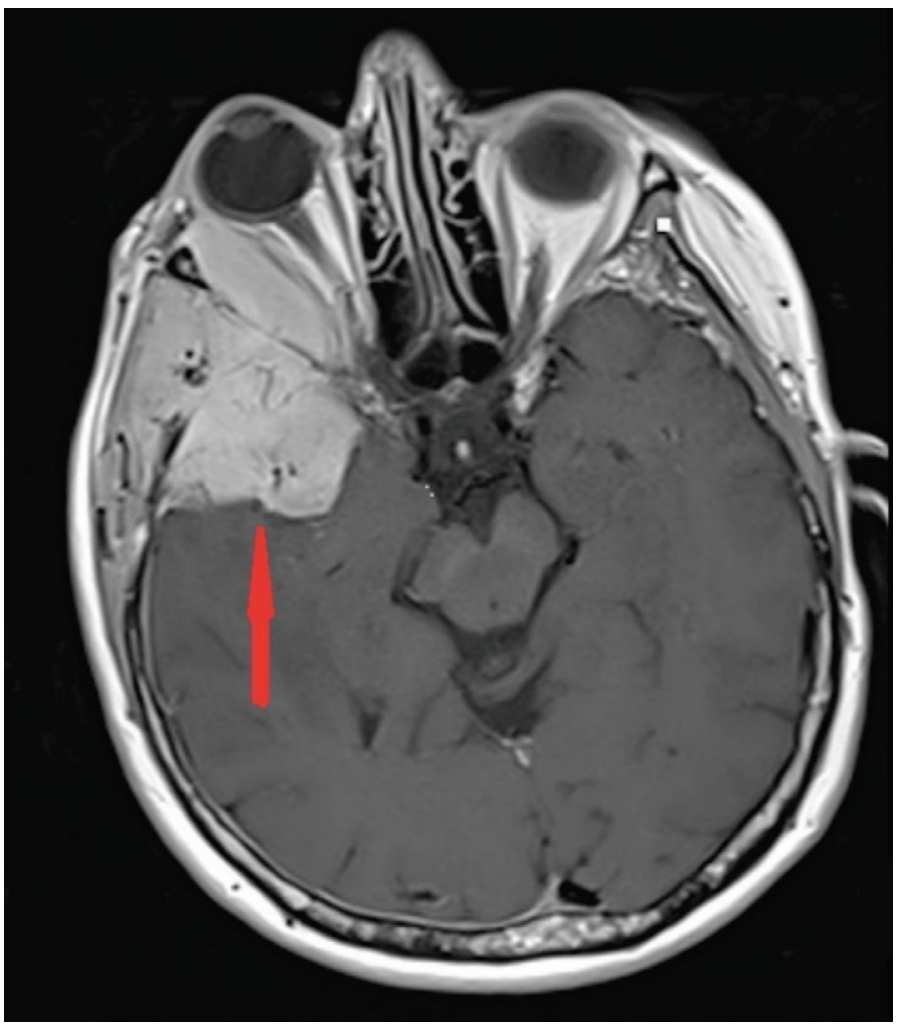

Figure 1. Cranial axial contrast magnetic resonance image before treatment: in the lateral aspect of the right orbit there is a mass lesion that expands and destroys the zygomatic bone and temporal lobe (red arrow). The mass lengthened in the cerebral parenchyma by invading the dura in the temporal region. serum protein electrophoresis. Brain magnetic resonance imaging showed a retro-orbital mass of $5 \times 6 \mathrm{~cm}$ in diameter extending to the right temporal region and cerebral parenchyma (Figure 1), leading to widespread edema (Figure 2). We did not evaluate the cerebrospinal fluid because it was an intracranial mass. The patient was diagnosed with recurrent MM and treated with VCD (bortezomib, cyclophosphamide, and dexamethasone). After four cycles of chemotherapy, significant clinical improvement including the regression of proptosis along with a decrease of radiological involvement was observed (Figure 3).

Keywords: Multiple myeloma, Orbita, Cerebrum

Anahtar Sözcükler: Multipl miyelom, Orbita, Serebrum

Conflict of Interest: The authors of this paper have no conflicts of interest, including specific financial interests, relationships, and/ or affiliations relevant to the subject matter or materials included.

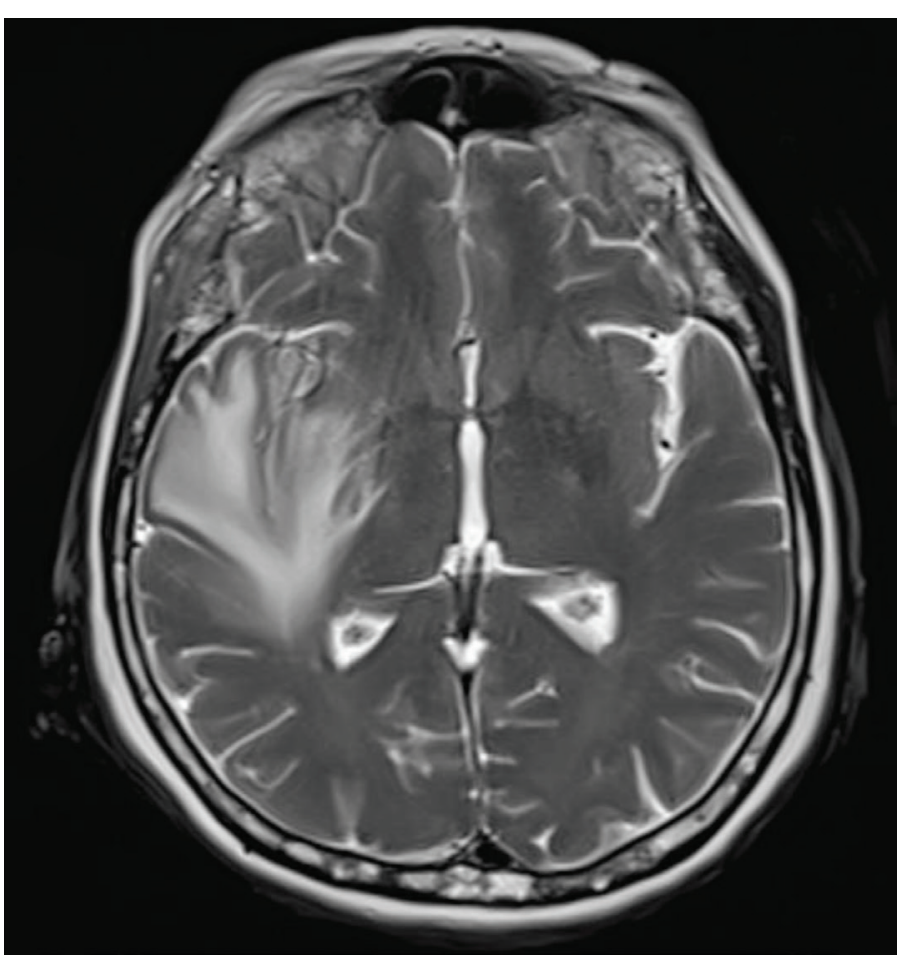

Figure 2. There is widespread edema (T2 axial images) around the joint due to cerebral parenchymal involvement. 


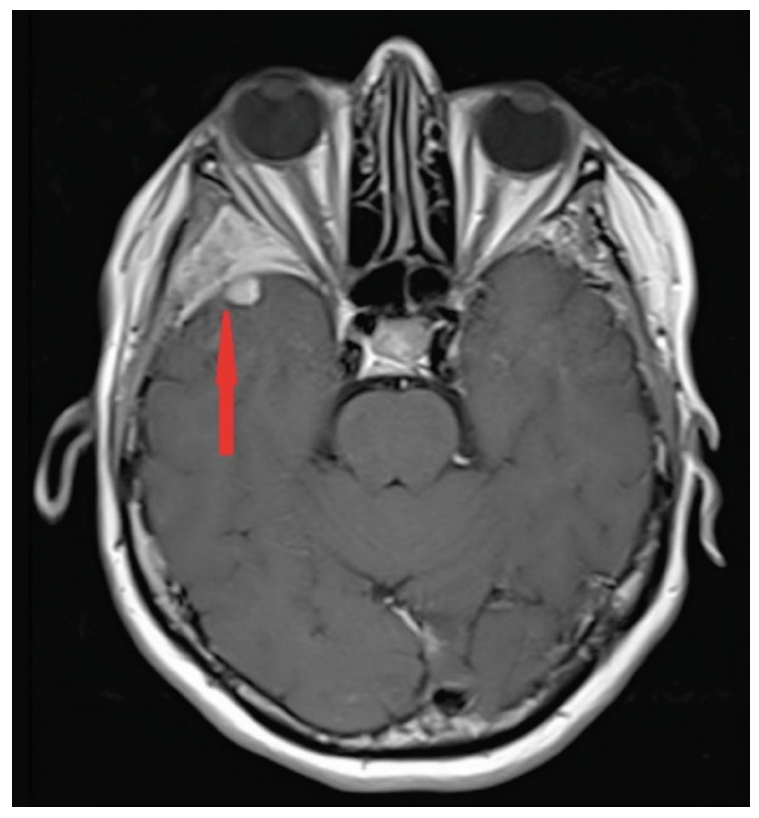

Figure 3. Significant regression is seen in the lesion after treatment (red arrow).

\section{References}

1. Fassas $A B$, Muwalla $F$, Berryman $T$, Benramdane $R$, Joseph $L$, Anaissie $E$, Sethi R, Desikan $R$, Siegel D, Badros A, Toor A, Zangari M, Morris $C$, Angtuaco E, Mathew S, Wilson C, Hough A, Harik S, Barlogie B, Tricot G. Myeloma of the central nervous system: association with high-risk chromosomal abnormalities, plasmablastic morphology and extramedullary manifestations. Br J Haematol 2002;117:103-108.

2. Nieuwenhuizen L, Biesma DH. Central nervous system myelomatosis: review of the literature. Eur J Haematol 2008;80:1-9.

3. Gangatharan SA, Carney DA, Prince HM, Wolf MM, Januszewicz EH, Ritchie DS, Harrison SJ. Emergence of central nervous system myeloma in the era of novel agents. Hematol Oncol 2012;30:170-174.

4. Gozzetti A, Cerase A, Lotti F, Rossi D, Palumbo A, Petrucci MT, Patriarca F, Nozzoli C, Cavo M, Offidani M, Floridia M, Berretta S, Vallone R, Musto P, Lauria F; GIMEMA (Gruppo Italiano Malattie Ematologiche dell'Adulto) Myeloma Working Party, Marchini E, Fabbri A, Oliva S, Zamagni E, Sapienza FG, Ballanti S, Mele G, Galli M, Pirrotta MT, Di Raimondo F. Extramedullary intracranial localization of multiple myeloma and treatment with novel agents: a retrospective survey of 50 patients. Cancer 2012;118:1574-1584.

5. Petersen SL, Wagner A, Gimsing P. Cerebral and meningeal multiple myeloma after autologous stem cell transplantation. A case report and review of the literature. Am J Hematol 1999;62:228-233. 